\title{
Ichthyofauna biodiversity of freshwater lakes in the Murmansk Region
}

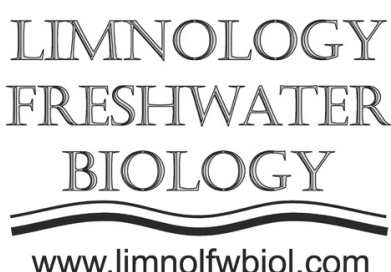

\author{
Koroleva I.M.*, Terentjev P.M. \\ Institute of the North Industrial Ecology Problems, Kola Science Centre, Russian Academy of Sciences, 184209, Apatity,
} Akademgorodok, 14a, Russia

\begin{abstract}
The Arctic ichthyofauna has low biodiversity and includes 460 species of fish $(2.0 \%$ of the world fauna); less than a third of them are freshwater species. There are less than 20 indigenous species in the lakes of the Murmansk Region. Salmoniformes, Perciformes, Osmeriformes, and Cypriniformes build the community core. The species diversity in the lakes of the Kola Peninsula is stable, but there is insignificant growth in the number of species due to the unintentionally introduced aquaculture objects. Water bodies sometimes successfully naturalize the latter. Illegal fishing dramatically causes the disappearance of valuable species in some lakes.

Global warming has not yet influenced the penetration of southern fish species. The expansion of native species in new water bodies is the reason for the most critical changes. Unimportant smelt Osmerus eperlamus expands its area extremely fast. A dramatic drop in the number of predators, such as trout and charr, highlights the problem of a rapid increase in paltry and weedy fish.
\end{abstract}

Keywords: Biodiversity, ichthyofauna, Salmoniformes, freshwater lakes, Subarctic.

\section{Introduction.}

Arctic freshwater bodies belong to the circumpolar region, the Iceland province, and are included in the North European district. The ichthyofauna of Arctic freshwater bodies has from 116 (Reshetnikov, 2007) to 150 (Chereshnev, 1996) species. All native species that occur in the lakes of Murmansk Region form four (4) fauna complexes according to G.V. Nikolsky (1980): arctic freshwater, boreal plain and pre-mountainous, and pontic. The significant elongation of areas in the meridional direction creates difficulty in defining the term "arctic species." The original classification includes: 1) arctic species, 2) arctic-boreal species, 3) boreal species, 4) south-boreal species, and 5) random species (Reshetnikov, 2007).

\section{Material and methods.}

Assessment of the freshwater limnic ichthyofauna biodiversity of the Murmansk Region is based on the results of their ichthyological studies and published fish lists (Chereshnev, 1996; Atlas ..., 2002; Reshetnikov, 2004, 2007).

\section{Results.}

Native freshwater fish in the Murmansk Region belong to one class (Actinopterygii), seven orders
(Salmoniformes, Cypriniformes, Gasterosteiformes, Perciformes, Osmeriformes, Gadiformes, and Esociformes), 7 families, 18 genera, and 19 species. Species bred in aquaculture extend the check-list by one order (Acipenseriformes), one family, one genus, and two species. The order Salmoniformes has the highest species richness (7). The Cypriniformes takes the next place (5).

The quantity of native species in the lakes of the Murmansk Region varies from 1 to 15 . It correlates with the lake size and altitude. Usually, the lakes are home for 10 - 12 fish species (Annotated ecological.., 2013). In isolated mountain lakes, the ichthyocenosis can be represented by one species (the Salvelinus alpinus charr or the Salmo trutta trout). Salmoniformes fish order dominates in the North of the Murmansk Region. The role of the order Cypriniformes (the roach Rutilus rutilus roach and thebream Abramis brama bream) increases in the water bodies of the southern and central zone.

Lake Imandra is the largest water body in the region. All fish species common for the northern part of the Kola peninsula live there. For the past one hundred years, 18 fish species lived in the lake, and two of them were invaders. One species (salmon) disappeared from the ichthyocenosis in the 1930s. The reason was the blockage of the spawning migration route (river Niva) after the dam construction. Two species bred in aquaculture naturalized in a local water area (the carp Cyprinus carpio carp and therainbow trout

*Corresponding author.

E-mail address: koririn@yandex.ru (I.M. Koroleva) 
Oncorhynchus mykiss rainbow trout). Currently, in addition to mykizhi, the Acipenser baerii sturgeon and the Huso huso x Acipenser ruthenus bester hybrid) are grown in the fish farm (Koroleva, Terentyev, 2019).

We can note several environmental forms for almost all species. Whitefish has at least four taxonomic groups by rank below the main species. There is evidence of the presence of slow-growing and fast-growing forms of arctic charr, trout, perch, and ruff. There may be a discrepancy between the large and small types for vendace and of smelt.

\section{Discussion}

A typical feature of the Arctic biota is low endemism, which indicates the youth in evolutionary terms, and incompleteness of the speciation processes. The presence of a species complex with a complex intraspecific structure (Atlas.., 2002), for example, whitefish and charr, serves as replenishment of small species number.

The principal environmental importance of the species complexes is an exploration of biomass-low and changing feeding base (Reshetnikov, 2007). Coinhabitance of a few environmental morphs of the same species solves the problem. Subspecies groups differ in growth rate, breeding periods, and morphological characters (structure of the oral apparatus) (Zubova et al., 2019, 2020).

\section{Conclusions}

The formation of species complexes and the presence of a significant number of in-species environmental forms can replenish the low species number of the ichthyofauna in the northern lakes. It dramatically increases the taxonomic diversity of the northern ichthyofauna.

\section{Acknowledgments}

This research was supported by research project No. 0226-2019-0045 and partially supported by the RFBR grant No. 18-05-60125 Arctic, and the RSF grant No. 19-77-10007. Interpretation of hydrobiological and ichthyological data was funded as part of the RFBR grant No. 18-05-60125 Arctic.

\section{References}

Annotated ecological catalogue of lakes of the Murmansk Region: the central and southwest areas of the Murmansk Region (basins of the Barents Sea, the White Sea and the Bothnia Gulf of the Baltic Sea). 2013. In: Kashulin N.A. (Ed.). Apatity: Publ. KSC RAS, (In Russian)

Chereshnev I.A. 1996. Annotated check-list of fish-like vertebrates and fishes from freshwaters of Arctic and adjacent area. Journal Ichthyology. V. 36. № 5: 597-608. (In Russian)

Koroleva I.M., Terentjev P.M. 2019. The fish community in Lake Imandra (Kola peninsula). Geography and Natural Resources. 4: 116-124. (In Russian) DOI: 10.21782/ GIPR0206-1619-2019-4(116-124).

Nikolsky G.V. 1980. Structure of species and conformity to fish variability. Moscow: Pischev. promyshlennosty. (In Russian)

Atlas of Russian freshwater fishes, vols. I and II. 2002. In: Reshetnikov Yu.S. (Ed.). Moscow: Nauka Press. (In Russian)

Reshetnikov Yu.S. 2004. Coregonoid fishes in Arctic water. Annales Zoologici Fennici. 41: 3-11.

Reshetnikov Yu.S. 2007. Ichthyofauna of the Arctic. In: Modern investigation of ichthyofauna in arctic and southern seas of the European part of Russia. Apatity: Publ. KSC RAS. (In Russian)

Zubova E.M., Kashulin N.A., Terentyev P.M. 2019. Biotic sympatry of whitefish Coregonus lavaretus (L.) in Kuetsjarvi lake (Pasvik river system, Murmansk region). Principles of the Ecology. 2: 3-20. (In Russian)

Zubova E.M., Kashulin N.A., Dauwalter V.A., Denisov D.B., Valkova S.A., Vandysh O.I., Slukovskii Z.I., Terentjev P.M., Cherepanov A.A 2020. Long-Term Environmental Monitoring in an Arctic Lake Pollution by Heavy Metal under Climate Change. Environments. 7(5) 34. doi.org/10.3390/ environments7050034 